\begin{tabular}{|c|c|c|}
\hline \multirow{2}{*}{ NA } & $\begin{array}{l}\text { Науковий вісник НлтУ України } \\
\text { Scientific Bulletin of UNFU }\end{array}$ & \begin{tabular}{|l|l} 
(C) 1 ISSN 1994-7836 (print) \\
BY ISSN 2519-2477 (online)
\end{tabular} \\
\hline & http://nv.nltu.edu.ua & \\
\hline H人т늘 & https://doi.org/10.15421/40280326 & $@ \triangle$ Correspondence author \\
\hline & $\begin{array}{l}\text { Article received } 25.04 .2018 \mathrm{p} . \\
\text { Article accepted } 26.04 .2018 \mathrm{p} .\end{array}$ & $\begin{array}{r}\text { V.P. Karashetskyy } \\
\text { Volodymyr10@gmail.com }\end{array}$ \\
\hline & УДк 536.21 & \\
\hline
\end{tabular}

В. П. Карашецький

Національний лісотехнічний університет Украӥни, м. Львів, Украӥна

\title{
АВТОМАТИЗОВАНА ВЕБ-СИСТЕМА ПІДБОРУ ТА ВІДОБРАЖЕННЯ ОПТИМАЛЬНИХ АПРОКСИМАНТ
}

Іноді таблично-задана функція є результатом експериментальних досліджень. Кожна з наведених точок, які входять у таблицю експериментальних даних, не $\epsilon$ абсолютно достовірною внаслідок впливу ряду випадкових чинників. Розроблено методику і програмне забезпечення автоматизованої веб-системи підбору та відображення оптимальних апроксимант для таблично-заданих двовимірних залежностей. Розроблене програмне забезпечення представляє веб-сайт. Цю веб-систему можна застосовувати для математичного опису досліджуваних процесів у різних предметних областях. Для отримання розв'язку задачі апроксимації застосовано метод найменших квадратів. Як апроксиманту використано повний поліном. Систему лінійних алгебраїчних рівнянь відносно коефіцієнтів апроксиманти розв'язують чисельним методом Гауса для кожного 3 повних поліномів першого, другого, та третього степенів. Якість апроксимації оцінюють за максимальним значенням коефіцієнта детермінації. Підбір оптимальної апроксиманти виконують після заповнення таблиці значень $x_{i}, y_{i}, z_{i}$ двовимірної залежності у вікні графічного інтерфейсу системи. Розроблена веб-система виводить діалогове вікно з виразом оптимальної апроксиманти або з повідомленням про неможливість ії отримати, якщо система лінійних алгебраїчних рівнянь відносно коефіцієнтів апроксиманти не має розв'язку, та відображає тривимірний графік оптимальної апроксиманти, який можна повертати, масштабувати, переміщати по осі $Z$, анімувати та зберегти у вигляді скриншоту, для цього застосовано бібліотеку Jzy3d на мові Јava.

Ключові слова: апроксимація; метод Гауса; метод найменших квадратів; оптимальна апроксиманта; повний поліном; сайт; Java; Jzy3d.

Вступ. Іноді таблично-задана функція є результатом експериментальних досліджень. Кожна з точок, які входять у таблицю експериментальних даних, не є абсолютно достовірною внаслідок впливу ряду випадкових чинників, до яких відносять похибки вимірювання, а також фактори, що випливають 3 неможливості чи доцільності ідеально точного дотримання умов експерименту в кожній з експериментальних точок.

Постає потреба якимось чином описати досліджуваний процес, тобто представити його у певній математичній залежності. Тому задача встановлення виду залежності однієї величини від іншої є важливою задачею як у науковому, так і в практичному плані.

Мета роботи полягає в розробленні методики i програмного забезпечення автоматизованої веб-системи підбору та відображення оптимальних апроксимант для таблично-заданих двовимірних залежностей.

Виклад основного матеріалу. Часто для побудови функціональних залежностей використовують метод апроксимації (від латинського слова "approximate", що означає "наближати"), суть якого полягає в тому, щоб замінити деяку залежність, наприклад $z=f(x, y)$, яка відома тільки для деякої кількості значень $x$ та $y$ на іншу залежність $z=g(x, y)$ так, щоб відхилення $f(x, y)$ від

$g(x, y)$ на множині значень $X$ та $Y$ було найменшим. Функцію $g(x, y)$ при цьому називають апроксимантою. Для побудови функціональних залежностей досліджуваних процесів використовують метод найменших квадратів (Filtc, Kotciuba, \& Gritciuk, 1991; Filts, 1995). Апроксимувати таблично-задану функцію методом найменших квадратів означає серед всіх апроксимант цього класу вибрати ту, для якої сума $s$ квадратів відхилень $\delta_{i}$ значень апроксиманти у вузлах $x_{i}$ та $y_{i}$ від табличних значень $z_{i}$ буде найменшою

$$
S=\sum_{i=1}^{m}\left(g\left(x_{i}, y_{i}\right)-z_{i}\right)^{2}=\sum_{i=1}^{m} \delta_{i}^{2} \rightarrow \min .
$$

Однак, при такій постановці задача апроксимації експериментальних даних має багато розв'язків. Для отримання єдиного розв'язку цієї задачі потрібно надати $g(x, y)$ певного вигляду, наприклад повного поліному $n$-го степеня

$$
\begin{gathered}
g(x, y)=a_{0}+a_{1} x+a_{2} y+a_{3} x y+a_{4} x^{2}+ \\
+a_{5} y^{2}+\ldots+a_{w-1} x^{n}+a_{w} y^{n}
\end{gathered},
$$

де $w=\frac{(2+n) !}{2 ! n !}$.

3 урахуванням (2) запишемо вираз (1) у вигляді

\section{Інформація про автора:}

Карашецький Володимир Петрович, канд. техн. наук, доцент, кафедра інформаційних технологій.

Email: Volodymyr10@gmail.com

Цитування за Дсту: Карашецький В. П. Автоматизована веб-система підбору та відображення оптимальних апроксимант. Науковий вісник НлтУ України. 2018, т. 28, № 3. С. 127-130.

Citation APA: Karashetskyy, V. P. (2018). Automated Web-Based System for Selecting and Displaying Optimal Approximants. Scientific Bulletin of UNFU, 28(3), 127-130. https://doi.org/10.15421/40280326 


$$
\begin{gathered}
S=\sum_{i=1}^{m}\left(a_{0}+a_{1} x_{i}+a_{2} y_{i}+a_{3} x_{i} y_{i}+a_{4} x_{i}{ }^{2}+a_{5} y_{i}{ }^{2}\right. \\
\left.+\ldots+a_{w-1} x_{i}{ }^{n}+a_{w} y_{i}{ }^{n}-z_{i}\right)^{2}=\sum_{i=1}^{m} \delta_{i}^{2} \rightarrow \min
\end{gathered}
$$

Очевидно, що величина $S$ - це багатопараметрична функція на множині $a_{i},(i=0, \ldots, w)$. Мінімум такої функції знаходиться за виконання умов вигляду:

$$
\begin{gathered}
\frac{\partial S}{\partial a_{0}}=0 ; \frac{\partial S}{\partial a_{1}}=0 ; \frac{\partial S}{\partial a_{2}}=0 ; \frac{\partial S}{\partial a_{3}}=0 ; \\
\frac{\partial S}{\partial a_{4}}=0 ; \frac{\partial S}{\partial a_{5}}=0 ; \ldots \frac{\partial S}{\partial a_{w-1}}=0 ; \frac{\partial S}{\partial a_{w}}=0 .
\end{gathered}
$$

Враховуючи (3), виконаємо спрощення і представимо (4) у вигляді системи лінійних алгебраїчних рівнянь відносно коефіцієнтів $a_{0}, a_{1}, a_{2}, \ldots a_{w}$

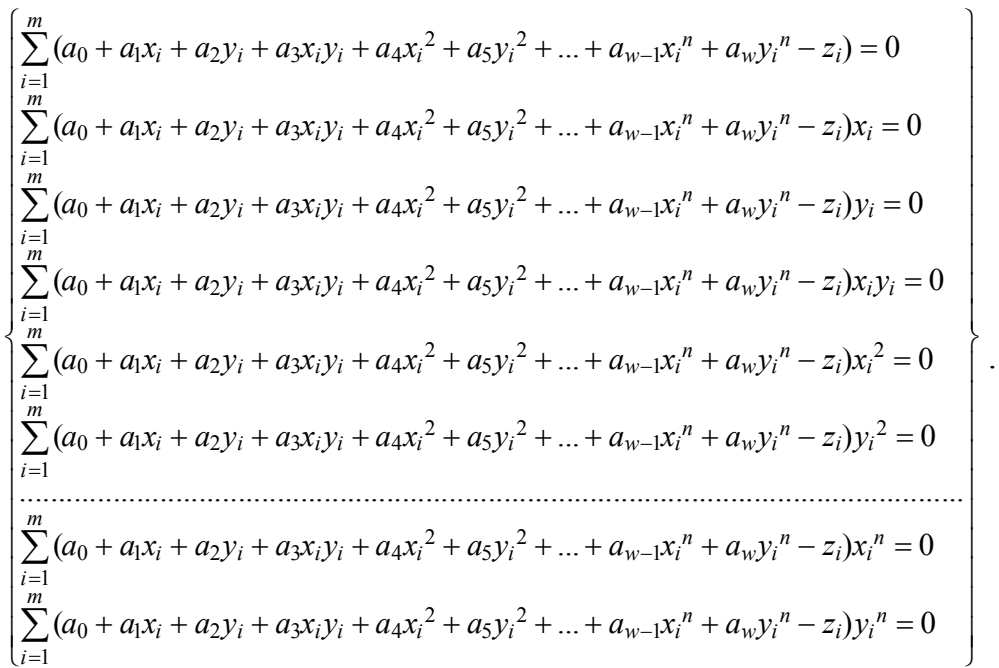

Розкриємо дужки та спростимо кожне з рівнянь системи окремо. Як результат отримаємо систему рівнянь такого виду

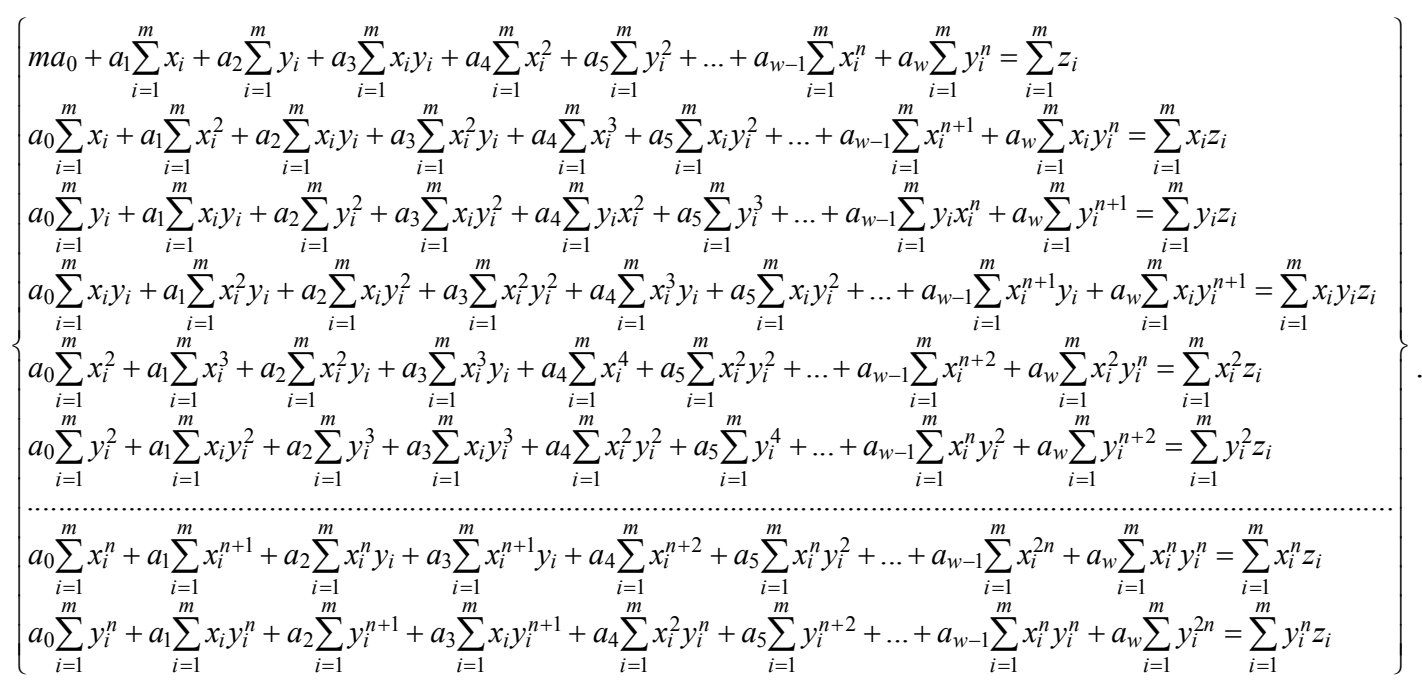

Розв'яжемо систему рівнянь виду (6) для кожного з повних поліномів першого, другого, та третього степенів одним із відомих чисельних методів, наприклад методом Гауса. Як результат отримаємо шукані коефіцієнти апроксимант для кожного з цих поліномів.

Якість апроксимації оцінюватимемо на підставі коефіцієнта детермінації $R^{2}$, який визначають (Coefficient of determination, 2018) так:

$$
R^{2}=1-\frac{S}{S_{t o t}},
$$

де:

$$
\begin{aligned}
S_{\text {tot }} & =\sum_{i=1}^{m}\left(z_{i}-\bar{z}\right)^{2} ; \\
\bar{z} & =\frac{1}{m} \sum_{i=1}^{m} z_{i} .
\end{aligned}
$$

Оптимальною вважатимемо ту з отриманих апроксимант (Filts, 1995; Gryciuk \& Dragan, 2016), у якої значення коефіцієнта детермінації є найбільшим.
Розроблене програмне забезпечення представляє веб-сайт, у головному вікні якого (рис. 1) натисненням на кнопку "Вхід" здійснюється перехід на реєстрацію.

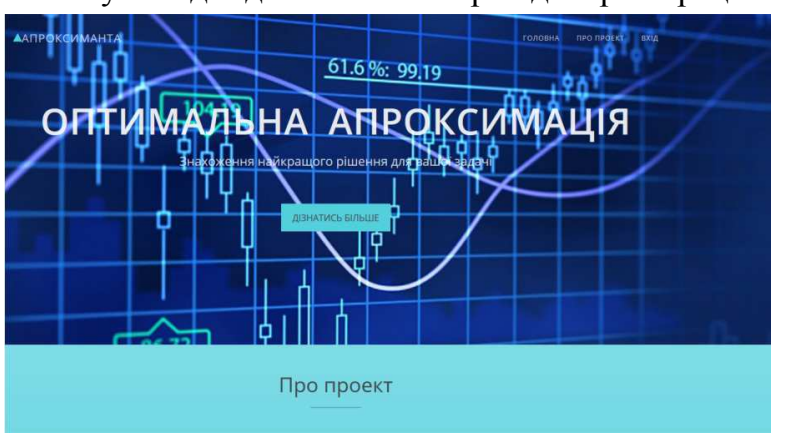

Рис. 1. Головне вікно сайту

Після успішного виконання реєстрації з'являється вікно графічного інтерфейсу системи (рис. 2). Спочатку користувачу необхідно порядково заповнити таблицю вхідних величин, наприклад, для залежності питомої теплоємності деревини $z$ (кДж/(кг·К) від абсолют- 
ної вологості $x(\%)$ і температури $y\left({ }^{\circ} \mathrm{C}\right)$. Для цього потрібно вводити у відповідні поля значення величин $x_{i}, y_{i}, z_{i}$ по кожному $i$-му вузлу і натискати кнопку "Ввести значення".

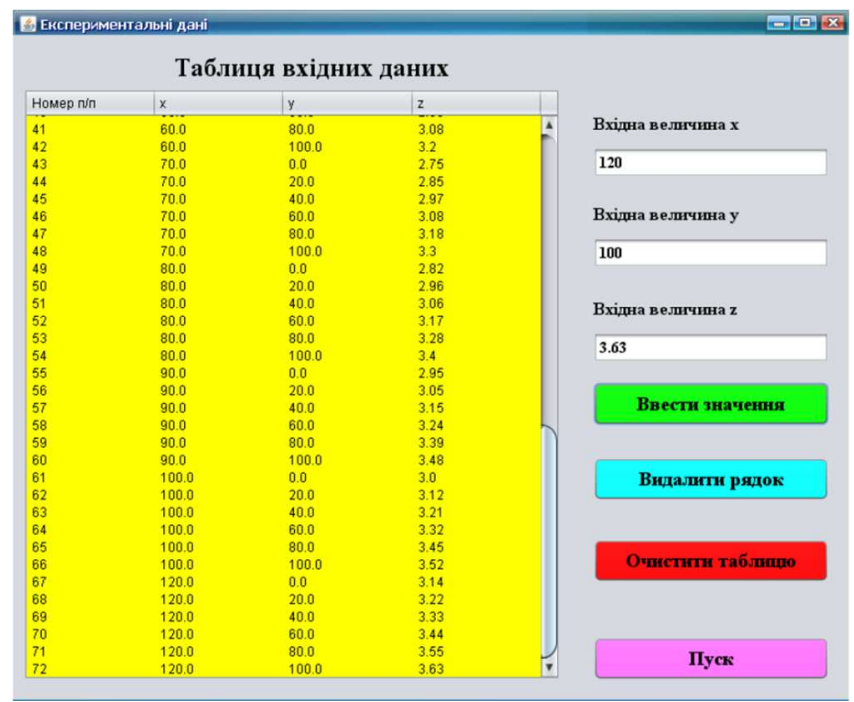

Рис. 2. Вікно графічного інтерфейсу системи

Після натискання кнопки "Ввести значення" з'являється діалогове вікно з повідомленням про введення вказаних значень (рис. 3) або нагадуванням про необхідність заповнення полів (рис. 4).

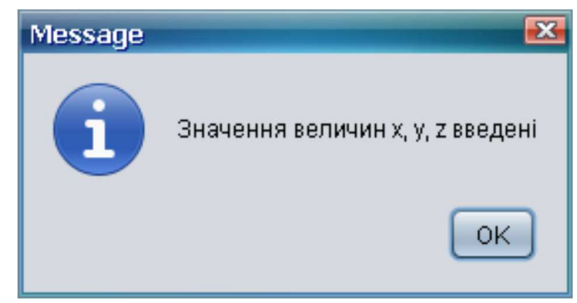

Рис. 3. Діалогове вікно з повідомленням про введення вказаних значень

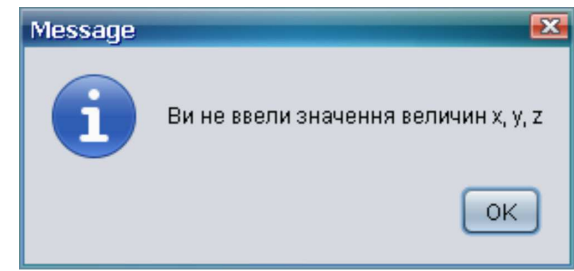

Рис. 4. Діалогове вікно з нагадуванням про необхідність заповнення полів

Кнопки "Видалити рядок" та "Очистити таблицю" призначені відповідно для видалення останнього введеного рядка таблиці та очищення вмісту усієї таблиці. При натисканні на кнопку "Видалити рядок" чи "Очистити таблицю" на екрані відображається діалогове вікно відповідно для видалення останнього введеного рядка таблиці (рис. 5) чи очищення таблиці (рис. 6), яке вимагає підтвердження або відміни вказаних дій.

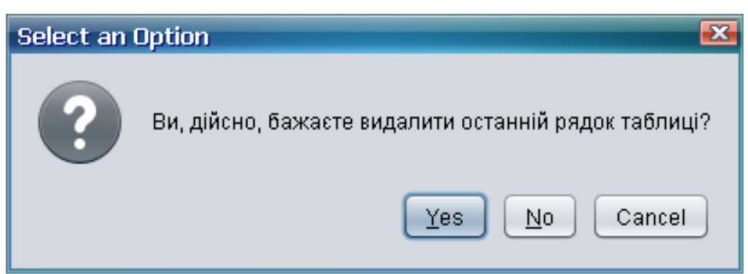

Рис. 5. Діалогове вікно підтвердження або відміни видалення останнього введеного рядка таблиці

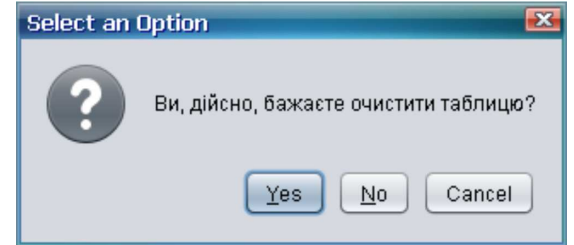

Рис. 6. Діалогове вікно підтвердження або відміни очищення вмісту усієї таблиці

Для підбору оптимальної апроксиманти потрібно натиснути кнопку "Пуск". Внаслідок цього спочатку 3'являється діалогове вікно 3 виразом оптимальної апроксиманти (рис. 7) або з повідомленням про неможливість іï отримати (рис. 8), якщо система рівнянь (6) не має розв'язку. Після закриття цього вікна відображається тривимірний графік оптимальної апроксиманти (рис. 9), який можна повертати, масштабувати, переміщати по осі $Z$, анімувати та зберегти у вигляді скриншоту, для цього застосовано бібліотеку Jzy3d (2018) мовою Java.

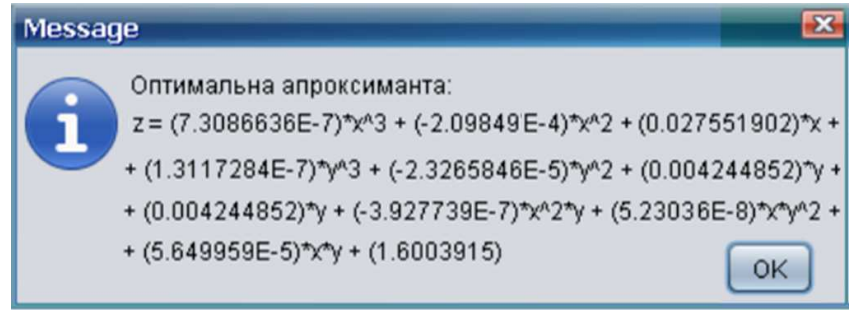

Рис. 7. Діалогове вікно з виразом оптимальної апроксиманти

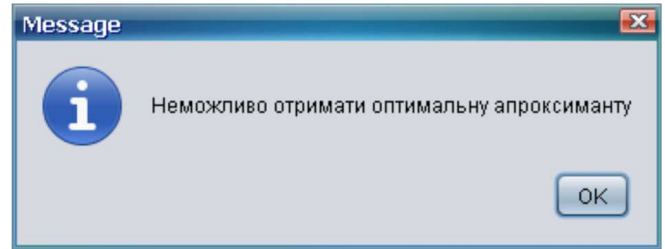

Рис. 8. Діалогове вікно з повідомленням про неможливість отримання оптимальної апроксиманти

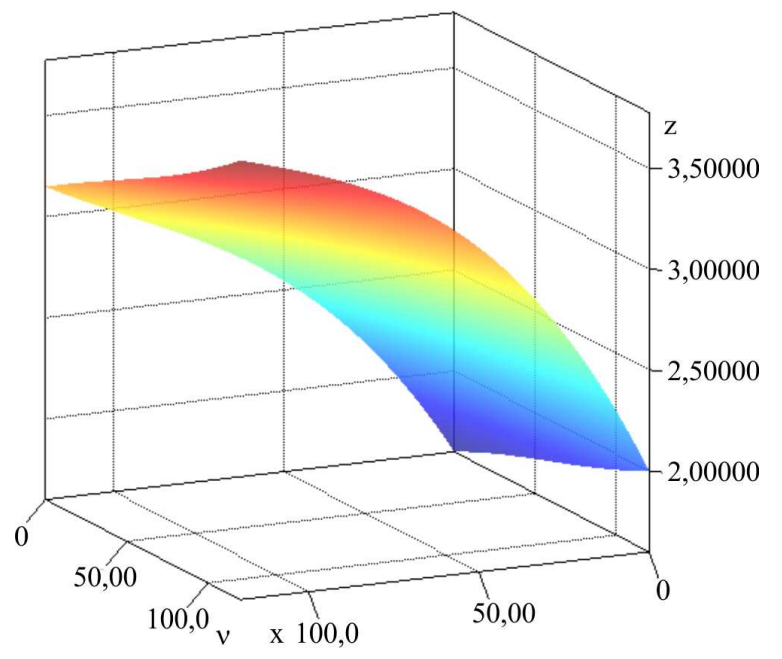

Рис. 9. Тривимірний графік оптимальної апроксиманти для залежності питомої теплоємності деревини від абсолютної вологості і температури

Висновки. Розроблено методику і програмне забезпечення автоматизованої веб-системи підбору та відображення оптимальних апроксимант для таблично-заданих двовимірних залежностей. Цю веб-систему можна застосовувати для математичного опису досліджуваних процесів у різних предметних областях. 


\section{Перелік використаних джерел}

Coefficient of determination. (2018). Retrieved from: https://en.wikipedia.org/wiki/Coefficient_of_determination

Filts, R. V., Kotciuba, M. V., \& Gritciuk, Iu. I. (1991). Algoritm vychisleniia na EVM mnogochlena Teilora i ego proizvodnykh. Elektromekhanika: Izvestiia vuzov, 5, 5-10. [In Russian].

Filts, R. V. (1995). Nablyzhennia tablychno zadanykh funktsi (interpoliatsiia ta aproksymatsiia). Konspekt lektsii z predmetu "Matematychni zadachi elektromekhaniky" dlia stud. spets. 1801 "Elektromekhanika". Lviv : Vyd-vo DU LP. 59 p. [In Ukrainian].
Gryciuk, Yu. I., \& Dragan, Ya. P. (2016). Numerical integration of table functions to one variable using Taylor polynomial. Scientific Bulletin of UNFU, 26(3), 350-360. Lviv: RVV NLTU Ukrainy. [In Ukrainian]

Gryciuk, Yu. I., \& Dragan, Ya. P. (2017). Numerical integration of tabular functions from two variables using the Taylor polynomial. Selection and processing of information, 44(120), 80-89. Lviv: Vyd-vo FMI im. H. V. Karpenka NAN Ukrainy. [In Ukrainian].

JZY3D. (2018). Open source API for 3d charts. Retrieved from: http://www.jzy3d.org/

\section{Наииональный лесотехнический университет Украины, г. Львов, Украина \\ АВТОМАТИЗИРОВАННАЯ ВЕБ-СИСТЕМА ПОДБОРА И ОТОБРАЖЕНИЯ ОПТИМАЛЬНЫХ АППРОКСИМАНТ}

Иногда таблично-заданная функция является результатом экспериментальных исследований. Каждая из приведенных точек, входящих в таблицу экспериментальных данных, не является абсолютно достоверной вследствие влияния ряда случайных факторов. Разработаны методика и программное обеспечение автоматизированной веб-системы подбора и отображения оптимальных аппроксимант для таблично-заданных двумерных зависимостей. Разработанное программное обеспечение представляет веб-сайт. Данную веб-систему можно применять для математического описания исследуемых процессов в различных предметных областях. Для получения решении задачи аппроксимации применен метод наименьших квадратов. В качестве аппроксимант использован полный полином. Система линейных алгебраических уравнений относительно коэффициентов аппроксимант решается численным методом Гаусса для каждого из полных полиномов первой, второй и третьей степеней. Качество аппроксимации оценивается по максимальному значению коэффициента детерминации. Подбор оптимальной аппроксиманты выполняется после заполнения таблицы значений $x_{i}, y_{i}, z_{i}$ двумерной зависимости в окне графического интерфейса системы. Разработана веб-система выводит диалоговое окно с выражением оптимальной аппроксиманты или сообщение о невозможности ее получить, если система линейных алгебраических уравнений относительно коэффициентов аппроксимант не имеет решения, и отображает трехмерный график оптимальной аппроксиманты, который можно поворачивать, масштабировать, перемещать по оси $Z$, анимировать и сохранить в виде скриншота, с этой целью применена библиотека Jzy3d на языке Java.

Ключевые слова: аппроксимация; метод Гаусса; метод наименьших квадратов; оптимальная аппроксиманта; полный полином; сайт; Java; Jzy3d.

V. P. Karashetskyy

Ukrainian National Forestry University, Lviv, Ukraine

\section{AUTOMATED WEB-BASED SYSTEM FOR SELECTING AND DISPLAYING OPTIMAL APPROXIMANTS}

A table-defined function tends to be sometimes the result of experimental research. Each of the points given in the table of experimental data is not absolutely reliable due to the influence of a number of random factors. Therefore, we have developed the technique and software of the automated web-system of selection and display of optimal approximants for tabulated two-dimensional dependencies. This web system can be used for a mathematical description of the investigated processes in various subject areas. To obtain a solution of the approximation problem, the classic method of least squares is applied. To obtain a unified solution of the approximation problem, we use a complete polynomial n-order. The system of linear algebraic equations with respect to the coefficients of approximants is solved by the numerical Gaussian method for each of the complete polynomials of the first, second, and third order. The approximation quality is estimated at the maximum value of the determination coefficient. An optimal approximant will be considered to be the one that has the highest value for the determination coefficient. The developed software represents the website in the main window of which users are re-registered. The window of the graphical interface of the system appears after the successful completion of the registration. First, the user must fill in the values of the input values in the table. To do this, you need to enter values $x_{i}, y_{i}, z_{i}$ in the corresponding table fields for each i-node. The automatic selection of the optimal approximation is performed after filling the table of values $x, y, z$ of two-dimensional dependence in the window of the graphical interface of the system. The developed web system displays a dialog with the expression of the optimal approximation or with the message that it cannot be obtained if the system of linear algebraic equations with respect to the coefficients of the approximation has no solution, and displays a three-dimensional chart of the optimal approximation, which can be rotated, scaled, moved along the $Z$ axis, animate and save as a screenshot. For this purpose, the Jzy3d library was used in Java.

Keywords: approximation; Gauss method; least squares method; optimal approximant; full polynomial; site; Java; Jzy3d. 